\title{
The Core of the Esssence of Humans of Pancasila According to Notonagoro: Autonomous and Responsible
}

\author{
Milton Thorman Pardosi ${ }^{1,2}$, Septiana Dwiputri Maharani ${ }^{2} \&$ Misnal Munir $^{2}$ \\ ${ }^{1}$ Faculty of Philosophy, Universitas Advent Indonesia, West Java, Indonesia \\ ${ }^{2}$ Faculty of Philosophy, Universitas Gadjah Mada, Yogyakarta, Indonesia \\ Correspondence: Milton Thorman Pardosi, Faculty of Philosophy, Universitas Advent Indonesia, West Jawa, \\ Indonesia. Tel: 62-8561-815-924. E-mail: mtpardosi@gmail.com
}

Received: December 9, 2019

Accepted: December 26, 2019

Online Published: December 27, 2019

doi:10.20849/ajsss.v4i4.696

URL: https://doi.org/10.20849/ajsss.v4i4.696

\begin{abstract}
Humans are different from plants and animals for humans have reason, mind, taste and soul. Many thoughts have arisen regarding humans in philosophy. One of them is Notonagoro's philosophical thinking that based on Pancasila. Two issues discussed were: what is the essence of humans of Pancasila according to Notonagoro and what is the core of the essence of humans of Pancasila according to Notonagoro. There are three essence of humans of Pancasila according to Notonagoro. They are three monopluralis of humans natures of Pancasila. Each of its consists of two elements. The three natures are: natural structure (susunan kodrat [elements: body and soul]), natural attribute (sifat kodrat [elements: individual beings and social beings]) and natural position (kedudukan kodrat [elements: independent beings and God's creatures]). These three natures must be kept in balance even though in the context of society, nation and state, three elements such as: soul, social beings and God's creatures take precedence. These three natures are centered in the soul which produces four godly characters (wisdom, simplicity, determination and justice). The three natures of humans of Pancasila according to Notonagoro can be abstracted into two core: "Autonomous" and "Responsible." Autonomous of humans of Pancasila includes three elements: body, individual beings and independent beings. Humans have freedom in developing these three elements, but, the freedom itself is not fully independent because humans are bound to the soul with its four godly characters. While responsible includes three other elements: soul, social beings and God's creatures. Humans have responsibilities both socially (law, ethics, norms, customs) and spiritually (God's creatures).
\end{abstract}

Keywords: autonomous, humans, nature, pancasila, responsible

\section{Introduction}

There are many concepts humans in philosophy. Abidin (2009) concluded some of these concepts, namely: first, the materialism that underlies its thinking that humans are material that occupy space and time, has broadness (res extensa) and is objective. Second, idealism which emphasizes that the true reality is spiritual in nature that is the existence of strength or spiritual reality behind every appearance or event. The essence of that spiritual reality is thinking (res cogitans). Furthermore, dualism which is a combination of materialism and idealism with an emphasis that the true reality is basically physical and spiritual (a combination of matter and spirit). While the thought of vitalism emphasizes that true reality is basically energy, power, strength or lust, non-physical forces that are irrational and instinctive. Fifth, existentialism that does not discuss humans in the abstract but specifically examines the concrete reality of humans as humans themselves are in their world. Sixth, structuralism which places the structure of language and culture as forces that determine human behavior and even consciousness. Finally, postmodernism which opposes not only the dominance of "I" that is free and able to break away from its cultural system, but also negates the dominance of social, cultural, political, artistic, economic, architectural, and even gender systems which are lame and tend to homogenize humanity.

Humans are different from plants or animals because they are higher than all other creatures created by God. Mangunwijaya (1999) emphasized that humans are amazing creatures because they can think, reflect, make their own decisions, be free from the certainty of fate, design, be creative, and even further educate their own intelligence. The Indonesian people recognize that humans are creatures created by God who have a body, mind and freedom of choice, thought and soul. The concepts of humans in Indonesia have actually been around for a 
long time. Many Indonesian philosophers have given their thoughts about humans and their spiritual aspects. There are at least nineteen Indonesian thinkers, started by Empu Kanwa $\left(11^{\text {th }}\right.$ century) to Sumantri Hardjoprakoso (1917-1970) who have explained what and how the nature of Indonesian people are (Roosseno, 2015).

Fourteen of the nineteen names appear in Dictionnaire des Philosophes, published in 1984. Some of these figures include: Mpu Kanwa ( $11^{\text {th }}$ century) emphasized the idea of perfect human unity only achieved through asceticism for the sake to meet with God which is the beginning and the end of everything that is phenomenal or noumenal. Humans also have to practice Dharma for the welfare of humanity (Roosseno, 2015). Ranggawarsita (1802-1873) stated that humans are a combination of four elements: earth, fire, air and water (Roosseno, 2015). Ki Hajar Dewantara (1889-1958), with Panca-Dharma, emphasized that human beings are free based on a national spirit characterized by autonomy, able to organize themselves (Roosseno, 2015). Soekarno (1901-1971) conveyed four main features of his thought, one of which was the religious life of Indonesian people as a concrete reality of the flesh and blood of Indonesian people (Roosseno, 2015). Nikolaus Driyarkara (1913-1967) emphasized that humans are individuals, unity that confirms themselves; humans exist in the world and form a sustainable world; sociality is existential; humans are historical creatures undergoing dialectical evolution (Roosseno, 2015). Hardjoprakoso (1917-1970) emphasized that the reality is essentially divine, which is also expressed through humans. Reality also includes radiant spiritual and eternal development. The real reality of humans is spiritual (Roosseno, 2015).

These diverse thoughts eventually came together as Pancasila. The five Precepts in Pancasila emphasize the concept of real Indonesian people. Indonesian people are human beings created by God, religious, just and civilized, social beings who want to live together with others, unite in peace, deliberation to reach consensus and aim for noble welfare together.

One of the nineteen Indonesian philosophical figures conveyed by Roosseno (2015) was Prof. Dr. Mr. Drs. Notonagoro (1905-1981). Notonagoro was an Indonesian philosopher who explored Pancasila and emphasized Pancasila as a philosophy. Notonagoro has made a major contribution to the development of the Pancasila as philosophy in Indonesia in general and the humans nature of Pancasila in particular. According to Notonagoro, the humans nature of Pancasila is important to be understood again due to various conditions and problems that occur in Indonesia today. Various acts of violence, reduced human values and morality, acts of corruption, attitudes of intolerance, "demo-crazy" are the effects of the fading understanding of the true values of humans of Pancasila.

\subsection{Statement of the Problems}

There are some issues will be discussed in this study:

1) What is the essence of humans of Pancasila according to Notonagoro?

2) What is the core thought of Notonagoro about the essence of humans of Pancasila?

\subsection{Research Objectives}

Through this study, readers may have right perceptions and understandings in Notonagoro's philosophical thinking. They are:

1) To understand the essence of humans of Pancasila according to Notonagoro.

2) To conclude and understand the core thought of Notonagoro about the essence of humans of Pancasila.

\section{Research Methodology}

Therefore, in completing this study, researcher used a qualitative research method in the field of philosophy sourced from library data. Qualitative research method focuses on quality naturally associated with understanding, concepts, values and characteristics inherent in the object of research (Kaelan, 2005). The source and and material for this research were obtained through library research that is from books related to the research topic. The main data was obtained from books written by Notonagoro related to the essence of humans nature in Pancasila. While secondary data were obtained from supporting sources related to the topic of this study.

\section{Analysis and Results}

\subsection{The Essence of Humans of Pancasila According to Notonagoro}

Plato, Aristotle and Thomas Aquinas as well as the analytic philosophy of language have influenced Notonagoro's thinking (Soeprapto, 2009). Notonagoro's thought on the philosophy of Pancasila and the essence 
of humans of Pancasila are much influenced by the philosophical thinking of Aristotle. According to Soeprapto (2009), the concept of Hylemorfism and Aristotle's abstraction method which focus on concrete sensory matters have become one of the starting points of Notonagoro's philosophical thinking in developing the philosophical thinking of Pancasila. Notonagoro finally arrived at the substantial of Pancasila and the meaning of five precepts of Pancasila are abstract, general, universal and remained unchanged.

Notonagoro (1995) asserts that five Precepts of Pancasila constitute a unified whole because the only supporter of the five Precepts is humans. The humans themselves believe in the one supreme GOD, humanity that is just and civilized, the unity of Indonesia, which is populist and socially just. Supadjar (1981) explained that Notonagoro saw the essence of humans of Pancasila as a monopluralis or a single compound consisting of three natures. "Monopluralis" means a multi-dimensional creature that consists of many elements but remains in a unified whole (Siswanto, 2013). Notonagoro (1967) concluded the monopluralis of the essence of humans of Pancasila specifically in the absolute core-content of the second Precept of Pancasila: conformity of the characteristics and conditions of and within our country with the essence of humanity composing, diversity/compound/single-minded or monopluralic, body-soul, intelligent-sense-will, individual beings-social beings, independent creature-God's creature, which raises the absolute necessity of both the bodily as well as the psychological and religious, which should be equally well cared for, in a balanced or harmonious and dynamic unity.

The concept of monopluralis of humans of Pancasila according to Notonanagoro consists of three natures, each of which consists of several monodualist elements. The three human natures of Pancasila are: natural structure (susunan kodrat), natural attribute (sifat kodrat) and natural position (kedudukan kodrat). These three natures "exist" in humans which must be maintained in balance. Bakry (1994) concluded that the balance of each of the three natures of monopluralis of humans of Pancasila is the basis of the philosophy of Pancasila so that the goal of the Indonesian state to achieve a just and prosperous society can be achieved.

The three essence of monopluralis of humans of Pancasila are: monodualist of natural structure: soul (its elements: reason or creativity which is directed to the reality of truth, a sense of the mentality and will) and body (its elements: inanimate objects, plants and animals); monodualist of natural attribute: individual beings and social beings; and monodualist of natural position: stand-alone or independent beings and God's creature (Notonagoro, 1995; Zubair, 1981). Notonagoro (1995) asserts that five Precepts in Pancasila contain the absolute things of the three human natures itself and all of them are one entity. Basically, the natural structure and the natural attribute if connected, the element of individual beings and the element of social beings each contain elements of body and soul. In essence, Notonagoro (1995) asserts that Pancasila has the basic nature of unity, in the form of these two human natures which constitute unity or monodualist. Therefore, Notonagoro (1967) emphasizes that these three natures of human must be equally well nurtured in a balanced or harmonious and dynamic unity.

Specifically, related to the natural attribute of humans, Notonagoro (1995) explains that the Indonesian state is not composed by individualis who stand alone and are not related to other individuals. The Indonesian state is also not composed collectively consisting of individuals who live together, who do not have themselves as individuals with their own circumstances, needs and interests that may differ from others. The State of Indonesia is a country consisting of individuals who live together both in birth and mysticism, who have individual and shared needs and interests, all of which are organized in a way that does not interfere with one another, but in balanced and dynamic cooperation. According to Bakry (1994), the natural attribute which most strongly influences humans' life and patterns which is also imbued by the natural structure and natural position, which has practical benefits in society and in the state.

Monopluralis of humans of Pancasila is a human who develops himself while still being bound to the community because the self individual is a citizen of the Republic of Indonesia. The monopluralis of humans of Pancasila will become a whole human being because it is able to make all its elements function in harmony. Body-soul, individual beings - social beings, freedom-attachment as God's creatures are considered as a whole in harmony, get the same treatment, so get the same opportunity to develop (Siswanto, 2013). Sutono (2017) asserted that the concept of a balanced human being is a human who considers balance as the basic norm because humans are social creatures as well as individual creatures which in their manifestations and nature show a relationship system that does not negate each other but develop each other.

\subsubsection{Natural Structure (Susunan Kodrat)}

The monodualis natural structure of humans of Pancasila is composed of body (Materialism) and soul (Idealism) (Notonagoro, 1995). Notonagoro (1995) emphasizes just as humans consist of body and soul, two elements 
which in themselves are of different types, contradict each other, but in realizing humans no longer contradict, instead unite in unity that cannot be separated. If separated, human beings will be lost, and the position and function of the soul and body will be lost as well.

Some important points related to the natural structure of humans are: first, the two elements of this natural structure affect the pattern of human life because both must be treated equally (Bakry, 1994). White (1933) emphasized that: "those who are sick in the body are nearly always sick in the soul, and when the soul is sick, the body is made sick" or mens sana in corpore sano (in a strong body there is a healthy soul). In other words, there is a close attachment between body and soul. Mental health affects the health of the body, and vice versa. Humans who have healthy souls will treat their bodies well and wisely.

Second, the unity of reason, taste and intention (elements of soul) will give rise to the ability to remain "right value" (tepat nilai) and "efficient" (tepat guna) to perform actions called wisdom or caution. Humans need four godly characters to maintain a balance of good behavior toward oneself (body), others (social beings) and God (God's creatures) (Zubair, 1981). Notonagoro provides four godly characters that must be built and possessed by humans, namely: wisdom, simplicity, determination and justice (Sumiyati, 2000).

Third, in the physical aspect (elements of organic inanimate objects, vegetative and animal living things) the main problem that humans face is meeting the needs of desire. The physical man also needs four gadly characters found in the soul in the matter of meeting the needs of his or her desires. Humans who have physicality will act according to the control of their souls that produce decisions that are "right-value" and "efficient." When humans cannot control their physical elements, humans will tend to damage their bodies, live just satisfies their desires which can be detrimental himself or herself and also the community.

Finally, Zubair (1981) explained that originally, Indonesian people seems also to tend to be more concerned with the development of the soul element rather than body element. This can be seen from the concept of four godly characters conveyed by Notonagoro who governed all human life.

\subsubsection{Natural Attribute (Sifat Kodrat)}

The monodualis natural attribute of humans of Pancasila consists of two elements: individual beings and social beings (Notonagoro, 1995). The natural attribute of humans as an individual beings cannot be separated from its natural attribute as a social beings. Human happiness, both body and soul (natural structure) comes not only from oneself as an individual beings but also as a social beings. This natural attribute must also be addressed in a balanced manner because focusing on one will cause the failure of humans to achieve complete happiness both individually and socially. White (1925) states that: "We are individually connected with our fellow men, a part of God's great whole, and we stand under mutual obligations. No man can be independent of his fellow men; for the well-being of each others. It is God's purpose that each shall feel himself necessity to others' welfare and seek to promote their happiness."

Some important points related to natural attribute of humans are: first, the two elements of the natural attribute of humans cannot be removed one of them. Sometimes individualistic traits will appear more dominant than social traits, or vice versa (Bakry, 1994). Damage to the soul will occur if humans are only individual and do not meet with other individuals. Conversely, social relations produce a reaction that is mutual attention and response (Zubair, 1981).

Second, these two elements of natural attribute affect the pattern of humans' life. This individual trait applies both to individuals and groups or society. Third, humans, as individual beings, are free to do and get their rights. However, because humans are also social beings, humans, in exercising their rights, do not forget their obligations as social beings and do not take the rights of others who are also individuals as themselves. Humans must not exceed the limits in obtaining their rights so that ignores the interests or rights of others (Siswanto, 2013).

Fourth, individual human beings are human beings who are aware of their actions and ability to take responsibility for their actions on their own personal risk to values, norms, morals, laws, customs and religious teachings. However, humans are social beings who live together with other humans so that this meeting brings satisfaction to the soul. Social relations produce mutual attention and response (Zubair, 1981).

Fifth, Zubair (1981) concludes that the unity of humans nature as individual beings and social beingss is stated in third Precept in Pancasila, namely "The Unity of Indonesia." Individual human beings perfect the survival and at the same time, as social beings, humans uphold the continuity of species and cultural civilization. Humans accept differences and similarities that exist and even develop both for the purpose of cooperation and organic unity. 
Notonagoro (1995) finally concluded that natural attribute of humans of Pancasila is seen in national and state life. The natural attribute of individual beings, in fact, sometimes according to circumstances, needs and interests, at one particular moment, arises and is more powerful than natural attribute of social beings. Natural attribute of social beings, at other times, sometimes arises and is more powerful than natural attribute of individual beings. This is a fact that appears in real life. However, Notonagoro (1995) asserts that the monodualist natural attribute of humans of Pancasila, the basis of statehood is personal human freedom as individuals and as social beings together and in the same position. Notonagoro (1995) further adds that this natural attribute of humans of Pancasila is universal because Indonesian people have a sacred mission, a sacred duty to themselves (in the person of the nation, in the person of the individual) and towards all nations, all over the world, all of humanity.

\subsubsection{Natural Position (Kedudukan Kodrat)}

The monodualis natural position of humans of Pancasila consists of two elements: independent beings and God's creatures (1995). Pancasila recognizes that humans are God's creatures. Some of the main things related to the natural position of human are: first, as an independent person, humans are free to create, are responsible for their own actions. However, all invention and actions are accounted for both in front of society (social beings) and before God (God's creatures) (Bakry, 1994). Since human were created, humans were given by God freedom of choice so that humans are free to determine their own life to obey God or not. Humans are not robots or machines without mind and soul (White, 1967).

Second, two elements of natural position affect the pattern of humans life if not developed in a balanced way. If it is more focused on independent beings, then humans will only rely on their own minds. As a result, the accepted rules of life are regulated on the basis of personal thought patterns without any influence from the teachings or words of God (religion). But if the opposite happens, humans are more focused as God's creatures, without regard for humans as an independent person, then, humans in life always rely on the teachings of God (religion) with a superficial interpretation without using consideration of reason. The issue that arises is being liberal or fanatical.

Third, Zubair (1981) explains that as individuals who are independent, humans have liberty and freedom in determining their actions and choices. This is called freedom of choice. Humans are free and independent in living their lives. But, liberty and freedom are obtained from God because humans are God's creatures.

Finally, Notonagoro (1967 \& 1995) emphasized that as creatures of God, humans must live in taklim and obedience to God Almighty. Taklim means to glorify, to see God as the greatest, the highest, and the happiest. While obedience means obey to God, faithful (courage) to God, fearing (feeling afraid because of respect or love, and therefore living righteously). The results of taklim and obedience are four godly characters (Sumiyati, 2000; Zubair, 1981).

Notonagoro, in the end, put more emphasis on humans as God's creatures rather than independent beings. The four godly characters found in the soul prove it. Independent beings are still associated with humans as individual beings (natural attribute). As individual beings and independent beings, humans not only have freedom or rights, but also obligations. That is why humans are not fully free to be independent without restrictions in living their lives. On the other hand, humans as individual beings and independent beings are also limited in their lives because they are social beings and God's creatures. The consequence of humans as God's creatures is that humans depend entirely on the Creator. Another consequence is that humans must worship God (religion) which is humans' right and obligation. At the same time, humans as God's creatures must live the teachings and religious values that are adhered to but not in conflict with Pancasila. Indonesian people must be obligatory and obedient to God Almighty (Notonagoro, 1995). Besides that, as creatures of God, humans of Pancasila are people who have a fear of committing sin or breaking the law because in the end the wrongdoing or sin is not just accounted before humans legally, but is also accountable before God Almighty on the day of judgment (hereafter).

\subsection{The Core Thought of Notonagoro About the Essence of Humans of Pancasila}

Researcher saw and concluded that monopluralis of humans of Pancasila that Notonagoro excavated, which consists of three natures and each nature consists of two elements, can be abstracted into two main core namely: "Autonomous - Responsible." First, humans of Pancasila are autonomous beings. Autonomous means "self-governed" (Salim, 2006; Departemen Pendidikan \& Kebudayaan, 1988). Autonomous beings of Pancasila is the conclusion of three elements of three human natures, namely: body (natural structure), individual beings (natural attribute) and independent creatures (natural position). The element of the human body is related to elements of humans as individual beings and independent beings because all three have aspects of autonomy. 
The intended freedom is not freedom that is independent (free from any ties or laws) but rather an autonomous freedom (free but bound to rules or laws).

Humans of Pancasila which is "autonomous" is a human being who is free to treat his body as he or she wishes, either to beautify or ugly the body, to make thin or fat, treat or let his of her body be damaged. Humans, on the other hand, are also autonomous humans in living their lives, making decisions, creating, inventing and acting for humans are individual beings and independent beings. Humans can choose not to be influenced by circumstances, the environment or the situation around them. However, autonomous of humans is still controlled by four godly characters that exist in the soul. Autonomous of humans are proof of the existence of humans of Pancasila who have the right to regulate the elements of the body, individual beings and independent beings.

The second conclusion, humans in Pancasila are "responsible" humans. Humans of Pancasila who is responsible is related to three elements of three human natures, namely: soul (natural structure), social beings (natural attribute) and God's creatures (natural position). The three elements together have a responsible aspect. This aspect of responsibility includes social aspects (social beings: ethics, norms, morals, laws, customs, etc.) and spiritual aspects (God's creatures: religion or belief) all of which are centered on human soul with four godly characters in it. Humans of Pancasila are autonomous but responsible. Humans can not be free without any restrictions, as they wish. Autonomous humans involve rights and obligations. That means, human autonomous must be accounted for legally both to society and the state (social beings) especially to God (God's creatures).

In essence, both natural structure (body and soul), natural attribute (individual beings and social beings) and natural position (independent beings and God's creatures) must be developed and carried out in a balanced and harmonious manner. This is humans of Pancasila who is autonomous and responsible. However, when humans are in the midst of society, living as a nation and state, then humans must prioritize natural elements such as soul, social beings and God's creatures (responsible).

\section{Conclusions}

There are four conclusions about problems as mentioned above:

1. This study discussed the nature of Indonesian people based on Pancasila. Pancasila, itself, is the basis of the state, ideology and philosophy of nation of Indonesian. There are some Indonesian philosophers who have tried to explore the nature or the essence of Indonesia people based on Pancasila. Many philosophical thoughts about the nature or the essence of Indonesia people have been given by these philosophers. One of them is proposed by Notonagaro. Notonagoro, actually, is the first philosopher who explored Pancasila as a philosophy. Notonagoro, in his efforts to explore Pancasila as a philosophy, found out that the essence of humans of Pancasila is monopluralis consisting of three natures. Each of these three natures consists of two monodualist elements. The three natures are: Natural Structure or Susunan Kodrat (elements: body and soul), Natural Attribute or Sifat Kodrat (elements: individual beings and social beings) and Natural Position or Kedudukan Kodrat (elements: independent beings and God's creatures). Notonagoro made the three monopluralis natures of humans of Pancasila with its monodualist elements as one of the basis of his philosophical thoughts of Pancasila.

2. These three natures "exist" in humans, cannot be eliminated either one. At the same time, the three natures must also be treated in a balanced and harmonious manner. Notonagoro saw that the three natures are centered on the soul (natural structure) because in this soul four godly characters are built and developed. These four godly characters will govern mankind in carrying out his or her life in elements: physical, individual beings and social beings, independent beings and God's creatures. The four godly characters are: wisdom, simplicity, determination and justice.

3. The core thought of the three monopluralis natures of humans of Pancasila according to Notonagoro are "Autonomous" and "Responsible." Autonomous of humans includes three elements of three human natures: physical (natural structure), individual beings (natural attribute) and independent beings (natural position). Autonomous is different from independent because autonomous is still bound to something while independent is free from any ties. Autonomous of humans is still bound to four godly characters: wisdom, simplicity, determination and justice in the soul.

4. Humans of Pancasila are also humans who are responsible because each of his or her action must be accounted for both legally (social beings: law, ethics, norms, ethics, customs, etc.) and spiritually (God's creatures). Responsible of humans is in the element of soul with its four godly characters. Notonagoro, in the end, put more emphasis on elements of soul, social beings and God's creatures in its development especially when humans are in the midst of society, nation and state especially as religious people. 
5. This study opens up avenues for future studies especially related to the nature of Indonesian people based on Pancasila such as: a comparison between philosophical thought of Notonagoro about the essence or nature of Indonesia people with other philosophical thoughts of human's nature, or the philosophical thought of Notonagoro about the essence of the nature of Indonesia people may be used as the material object to be examined using other philosphical thought as the formal object, or in topics related to the development of the whole being based on Pancasila, or the development of Indonesian human character based on Pancasila itself.

\section{Acknowledgements}

I would like to thank Dr. Septiana Dwiputri Maharani (Advisor) and Dr. Misnal Munir (Associate Advisor) who have provided essencial inputs, revisions, improvements and for all academic support.

\section{References}

Abidin, Z. (2009). Filsafat manusia: Memahami manusia melalui filsafat. Bandung: Remaja Rosdakarya.

Bakry, N. (1994). Orientasi filsafat pancasila. Yogyakarta: Liberty.

Departemen Pendidikan \& Kebudayaan. (1988). Kamus besar bahasa indonesia. Jakarta: Balai Pustaka.

Kaelan, M. S. (2005). Metode penelitian kualitatif bidang filsafat. Yogyakarta: Paradigma.

Mangunwijaya, Y. B. (1999). Manusia pascamodern, semesta, dan tuhan: Renungan filsafat hidup manusia modern. Yogyakarta: Kanisius.

Notonagoro. (1967). Beberapa hal mengenai falsafah pantjasila. Jakarta: Pantjuran Tudjuh.

Notonagoro. (1995). Pancasila secara ilmiah populer. Jakarta: Bumi Aksara.

Roosseno, T. H. N. (2015). Tentang manusia indonesia, dsb. Jakarta: Yayasan Pustaka Obor Indonesia.

Salim, P. (2006). The contemporary english-indonesia dictionary: With british and american pronunciation and spelling (Volume 1). N.p.: Media Eka Pustaka.

Siswanto, D. (2013). Manusia dalam pandangan kristen: Relevansinya dengan manusia monopluralis dalam pancasila. Yogyakarta: Fakultas Filsafat UGM Yogyakarta.

Soeprapto, S. (2009). Dasar ontologis pancasila menurut notonagoro dan relevansinya dengan kelangsungan jari diri bangsa. Unpublished doctoral dissertation, Yogyakarta: Fakultas Filsafat, Universitas Gadjah Mada.

Sumiyati, A. (2000). Konsep filsafat pendidikan pancasila notonagoro: Implementasinya dalam pengembangan manusia indonesia seutuhnya. Unpublished masteral thesis, Yogyakarta: Fakultas Filsafat, Universitas Gadjah Mada.

Supadjar, D. (1981). Persiapan menjadi manusia berilmu menurut prof. Notonagoro. In Pengantar ke alam pemikiran kefisafatan prof. dr. drs. mr. notonagoro. Yogyakarta: Universitas Gadjah Mada.

White, E. G. (1925). Christian service. Hagerstown, MD: Review and Herald Publishing Association.

White, E. G. (1933). A Call to medical evangelism and health education. Nashville, TN: Southern Publishing Association.

White, E. G. (1967). In heavenly places. Washington, D.C.: Review and Herald Publishing Association.

Zubair, A. C. (1981). Pengantar kepada konsep manusia indonesia seutuhnya in memoriam prof. drs. mr. notonagoro. In Pengantar ke alam pemikiran kefilsafatan prof. dr. drs. mr. notonagoro. Yogyakarta: Yayasan Pembina Fakultas Filsafat, Universitas Gadjah Mada.

\section{Copyrights}

Copyright for this article is retained by the author(s), with first publication rights granted to the journal.

This is an open-access article distributed under the terms and conditions of the Creative Commons Attribution license (http://creativecommons.org/licenses/by/4.0/). 